\title{
Inhibition of Degranulation of RBL-2H3 Cells by Extracts and Compounds from Armillaria ostoyae
}

\section{(c) (). $\$$ Version 1}

\section{Authors}

Simon Merdivan ${ }^{1}$, Kristina Jenett-Siems ${ }^{2}$, Karsten Siems ${ }^{3}$, Timo Niedermeyer ${ }^{4}$, Michael J. Solis ${ }^{5,6}$, Martin Unterseher ${ }^{5}$, Ulrike Lindequist ${ }^{1}$

\section{Affiliations}

1 Institute of Pharmacy, Ernst-Moritz-Arndt University Greifswald, Greifswald, Germany

2 Institute of Pharmacy, Freie Universität Berlin, Berlin, Germany

3 AnalytiCon Discovery GmbH, Potsdam, Germany

4 Interfaculty Institute of Microbiology and Infection Medicine, Eberhard Karls University Tübingen, Tübingen, Germany

5 Institute of Botany and Landscape Ecology, Ernst-Moritz-Arndt University Greifswald, Greifswald, Germany

6 Department of Natural Sciences, College of Science and Information Technology, Ateneo de Zamboanga University, Zamboanga City, Philippines

Key words

Armillaria ostoyae, Physalacriaceae, RBL-2H3, sesquiterpene aryl esters, $\beta$-hexosaminidase assay, melleolide, cytotoxicity

received July 22, 2016

revised November 4, 2016

accepted November 9, 2016
Bibliography

DOI http://dx.doi.org/10.1055/s-0042-121608

Planta Med Int Open 2017; 4: 1-7 @ Georg Thieme Verlag KG Stuttgart · New York | ISSN 2199-157X

\section{Correspondence}

Simon Merdivan

Institute of Pharmacy, Pharmaceutical Biology, Ernst-Moritz-Arndt University Greifswald

Felix-Hausdorff-Str. 1, 17487 Greifswald, Germany

Phone: +493834864864 , Fax: +493834864885

merdivans@uni-greifswald.de

丹 Supporting information available online at http://www.thieme-connect.de/products

\section{ABSTRACT}

Armillaria ostoyae (Romagn.) Herink is an edible honey mushroom from the family Physalacriaceae (Agaricales, Basidiomycota). Dichloromethane extracts of mushroom mycelium and fruiting bodies exhibited a significant degranulation inhibiting effect on RBL-2H3 cells using noncytotoxic concentrations. Bioactivity-guided fractionation of the mycelial dichloromethane extract led to the isolation of sesquiterpen aryl esters. Methyl linoleate could also be isolated. These substances were obtained from $A$. ostoyae for the first time, with one compound representing an undescribed natural product. Purified compounds melleolide $\mathrm{H}$ and $\mathrm{J}$ inhibited degranulation significantly. A. ostoyae could be a candidate for support of allergy treatments.

$\begin{array}{ll}\text { ABBREVIATIONS } \\ \text { BSA } & \text { bovine serum albumin } \\ \text { CTAB } & \text { cetyltrimethyl ammonium bromide } \\ \text { DNP-HSA } & \text { 2,4-dinitrophenyl human serum albumin } \\ \text { HBSS } & \text { Hank's balanced salt solution } \\ \text { ITS } & \text { internal transcribed spacer } \\ \text { NRU } & \text { neutral red uptake assay } \\ \text { P-NAG } & \text { 4-nitrophenyl- } N \text {-acetyl- } \beta \text {-D-glucosaminide }\end{array}$

\section{Introduction}

During our investigations of biologically active fungi, Armillaria ostoyae (Romagn.) Herink [1], a basidiomycete belonging to the family Physalacriaceae, came into focus, as it affected degranulation in RBL-2H3 cells. The species is commonly known as edible mushroom, but it also occurs as a devastating pathogen of various tree species causing serious economic losses in forestry all over the world [2]. The mechanisms of host infection as well as hostpathogen interactions have been studied intensively [3-7]. In addition, Armillaria mushrooms attract a wider interest, for instance, as the world's biggest living organism [8] or as a producer of bioluminescence [9]. A broad variety of antibacterial and cytotoxic sesquiterpene aryl esters were isolated from the genus Armillaria, especially Armillaria mellea [10-20], but also Armillaria novae-zelandiae [21] and Armillaria tabescens [22]. In this manuscript, degranulation inhibiting effects of extracts from fruiting bodies and cultivated mycelium as well as bioactivity-guided isolation of compounds from the mycelium of $A$. ostoyae are described. Degranulation is the process in which cells release secretory products stored in secretory granules by exocytosis. It is an important feature of many immune cells, e.g., for release of mediators [23]. Inhibition of degranulation can result in the blocking of inflammatory or allergic reactions. 


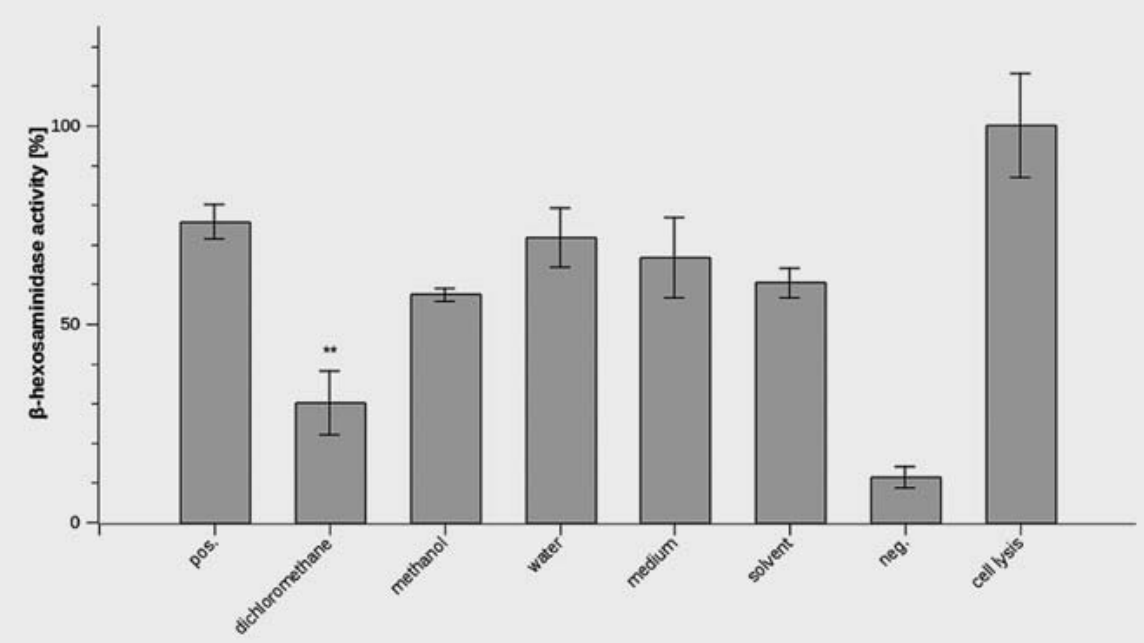

- Fig. 1 Inhibition of degranulation of RBL-2H3 cells by extracts from the mycelium of $A$. ostoyae and medium; pos: antibody-stimulated (without test substance); neg: unstimulated (without antibody and test substance). Concentration $=90 \mu \mathrm{g} / \mathrm{mL}$, Welch's test against solvent, $n \geq 4$.

\section{Results}

Three different extracts made with dichloromethane, methanol, and water were tested in a degranulation assay. Dichloromethane and methanol extracts from the mycelium of $A$. ostoyae exhibited significant degranulation inhibitory effects on RBL-2H3 cells ( $\vee$ Fig. 1). The Soxhlet dichloromethane extract was fractionated on a silica gel column with an $n$-hexane/ethanol/dichloromethane/methanol gradient. Fractions 2-4 were subjected to column chromatography using a toluene/acetone gradient from which fractions were also tested in the degranulation assay. Fractions 1 , 2, 4, and 5 exhibited inhibitory activity, while fractions 3, 7, 9, and 11 did not. Known purified compounds melleolide $\mathrm{H}$ (purity $\geq 93.5 \%$ ) and ( purity $\geq 95.4 \%$ ), obtained from fraction 1 , showed significant degranulation inhibition of RBL-2H3 cells. Other substances could be isolated only in much smaller amounts and were not tested. The potency of melleolide $\mathrm{H}$ was nearly one order of magnitude weaker than melleolide J. Again, the potency of the reference substance quercetin was one order of magnitude stronger than melleolide J. Quercetin had an $\mathrm{IC}_{50}$ of $6.7 \mu \mathrm{M}$, a value in accordance with the literature [24]. The biological effects are summarised in $>$ Table $\mathbf{1}$.

Dichloromethane extracts and pure compounds obtained from A. ostoyae were tested for cytotoxic effects on RBL-2H3 cells using the NRU assay. The dichloromethane extract of the fruiting body exhibited no cytotoxic effect after $1 \mathrm{~h}$ (approximately the time necessary for degranulation testing) and a weak cytotoxic effect after $24 \mathrm{~h}$. The $\mathrm{IC}_{50}$ of the cytotoxicity of the mycelial extracts was one order of magnitude higher than the $\mathrm{IC}_{50}$ for degranulation inhibition after $1 \mathrm{~h}$ and also after $24 \mathrm{~h}$. Etoposid as a reference substance has an $\mathrm{IC}_{50}$ of $0.9 \mu \mathrm{M}$. The cytotoxicity $\mathrm{IC}_{50}$ can be found in $>$ Table $\mathbf{1}$.

After repeated column chromatography on silica gel, from 11 fractions, 8 sesquiterpene aryl esters and methyl linoleate were
- Table 1 Biological effects of extracts/substances from A. ostoyae.

\begin{tabular}{|c|c|c|}
\hline $\begin{array}{l}\text { Dichloromethane } \\
\text { extracts/substances }\end{array}$ & $\begin{array}{l}\mathrm{IC}_{50} \text { Inhibition of } \\
\text { degranulation }\end{array}$ & $\begin{array}{l}\mathrm{IC}_{50} \\
\text { Cytotoxicity }\end{array}$ \\
\hline $\begin{array}{l}\text { Fruiting body } \\
\text { A. ostoyae }\end{array}$ & $115.1 \mu \mathrm{g} / \mathrm{mL}$ & $\begin{array}{r}1 \mathrm{~h}:>500 \mu \mathrm{g} / \mathrm{mL} \\
24 \mathrm{~h}: 183.6 \mu \mathrm{g} / \mathrm{mL}\end{array}$ \\
\hline Mycelium A. ostoyae & $21.5 \mu \mathrm{g} / \mathrm{mL}$ & $\begin{array}{c}1 \mathrm{~h}: 111.1 \mu \mathrm{g} / \mathrm{mL} \\
24 \mathrm{~h}: 18.5 \mu \mathrm{g} / \mathrm{mL}\end{array}$ \\
\hline Melleolide H & $99.9 \mu \mathrm{mol} / \mathrm{L}$ & $24 \mathrm{h:} 23.6 \mu \mathrm{mol} / \mathrm{L}$ \\
\hline Melleolide J & $39.5 \mu \mathrm{mol} / \mathrm{L}$ & $24 \mathrm{h:} 20.8 \mu \mathrm{mol} / \mathrm{L}$ \\
\hline Quercetin & $6.7 \mu \mathrm{mol} / \mathrm{L}$ & $24 \mathrm{h:}: 185.2 \mu \mathrm{mol} / \mathrm{L}$ \\
\hline Etoposid & n.d. & $24 \mathrm{~h}: 0.9 \mu \mathrm{mol} / \mathrm{L}$ \\
\hline
\end{tabular}

isolated by semipreparative HPLC. The yields were between $0.0093 \%$ and $0.091 \%$ of dried biomass. Structures of isolated substances can be found in > Fig. $\mathbf{2}$.

The isolated meroterpenes were identified as melleolide $C$ [10] (2), H [11] (3) and J [21] (4), melledonal C [12] (5), 10-hydroxymelleolide [15] (6), armillarin [22] (7), and armillaridin [25] (8) by means of mass spectrometry and NMR spectroscopy, while methyl linoleate (9) was identified by NMR spectroscopy. 13-Hydroperoxyarmillarinin (1) displayed a peak at $\mathrm{m} / \mathrm{z} 503.1443$ [M + $\left.\mathrm{Na}^{+}\right]^{+}(\delta=-0.040 \mathrm{ppm})$ in the HRESIMS in the positive mode, corresponding to a molecular formula of $\mathrm{C}_{24} \mathrm{H}_{29} \mathrm{ClO}_{8}$ and identical to melledonal $\mathrm{C}$. The NMR spectra of 1 and 5 showed strong similarities, but, in contrast to 5 , substance 1 possessed just one hydroxymethylene group at $\delta_{\mathrm{H}} 5.60(\mathrm{t}, 8.7 \mathrm{~Hz}, \mathrm{H}-5)$. An additional methylene residue was observed at $\delta_{\mathrm{H}} 1.71(\mathrm{dd}, 2.0,13.0 \mathrm{~Hz}, \mathrm{H}$ $10 \beta)$ and $\delta_{\mathrm{H}} 1.32(\mathrm{dd}, 11.6,13.0 \mathrm{~Hz}, \mathrm{H}-10 \alpha)$, which coupled to $\mathrm{H}$ 9 at $\delta_{\mathrm{H}} 2.41$ (dd, 2.0, $11.6 \mathrm{~Hz}$ ). Furthermore, a suspicious downfield shift of $\mathrm{C}-13$ ( $\delta_{C} 89.5$ versus $\delta_{C} 77.6$ in 5 ) was observed, leading to the assumption that there should be a hydroperoxide group 


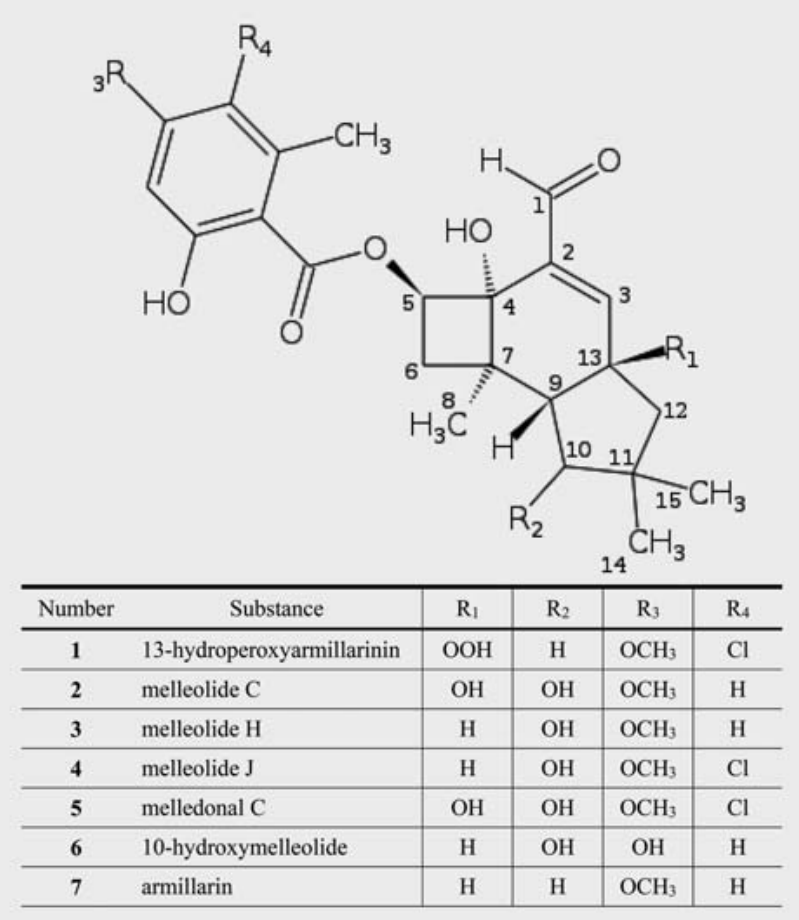

- Fig. 2 Structures of isolated substances.

in this position. Similar shift differences are described, e.g., for peroxides obtained from Artemisia alba [26]. For NMR data of 1 see $>$ Table 2. Thus, 1 was identified as the 13-hydroperoxy derivative of armillarinin [27]. All isolated compounds were described for the first time from the mycelium of $A$. ostoyae. Compound 1 represents an up to now unknown natural product. Other characteristics of isolated compounds can be found in "Characterisation of isolated compounds".

\section{Discussion}

Species determination within the genus Armillaria is very complex, as they represent more of a species aggregate than distinctive species. Sequence analysis showed the mycelial material to cluster in the $A$. ostoyae group, which was therefore taken as the species of the mycelium. From the mycelium of $A$. ostoyae, different metabolites were purified using bioactivity-guided isolation. Dichloromethane extracts from fruiting bodies and mycelium had significant degranulation inhibiting effects on RBL-2H3 cells. Purified compounds 3 and 4 exhibited an inhibition of degranulation in differing potencies, with the halogenated derivate showing a higher potency than the unhalogenated derivate. These compounds potentially contribute to the activity of the extract. Sesquiterpene aryl esters from Armillaria sp. were already found to possess antibacterial $[10,16]$, antifungal $[28]$ and cytotoxic $[29,30]$ effects and to inhibit the growth of lettuce [25]. Inhibition of degranulation of RBL-2H3 cells was observed for the first time in A. ostoyae,
- Table 2 NMR data of 13-hydroperoxyarmillarinin $(500 \mathrm{MHz}$, $\delta$ [ppm], J [Hz]) in $\mathrm{CDCl}_{3}$.

\begin{tabular}{|c|c|c|}
\hline Atom & $\delta_{\mathrm{H}}$ & $\delta_{\mathrm{c}}$ \\
\hline 1 & $9.57 \mathrm{~s}$ & 196.4 \\
\hline 2 & & 137.8 \\
\hline 3 & $6.98 \mathrm{~s}$ & 150.2 \\
\hline 4 & & 75.6 \\
\hline 5 & $5.60 \mathrm{t}(8.7)$ & 75.3 \\
\hline 6 & $2.11 \mathrm{dd}(8.7,11.1)$ & 32.6 \\
\hline \multicolumn{3}{|c|}{$2.04 \mathrm{dd}(8.7,11.1)$} \\
\hline 7 & & 37.4 \\
\hline 8 & $1.32 \mathrm{~s}$ & 22.1 \\
\hline 9 & $2.41 \mathrm{dd}(2.0,11.6)$ & 46.8 \\
\hline 10 & $1.71 \mathrm{dd}(2.0,13.0)$ & 43.6 \\
\hline \multicolumn{3}{|c|}{$1.32 \mathrm{dd}(11.6,13.0)$} \\
\hline 11 & & 35.9 \\
\hline 12 & $2.38 \mathrm{~d}(14.5)$ & 52.1 \\
\hline \multicolumn{3}{|c|}{$1.71 \mathrm{~d}(14.5)$} \\
\hline 13 & & 89.5 \\
\hline 14 & $1.15 \mathrm{~s}$ & 30.2 \\
\hline 15 & $1.02 \mathrm{~s}$ & 31.1 \\
\hline $1^{\prime}$ & & n.d. \\
\hline $2^{\prime}$ & & 106.7 \\
\hline $3^{\prime}$ & & 163.3 \\
\hline $4^{\prime}$ & $6.43 \mathrm{~s}$ & 99.3 \\
\hline $5^{\prime}$ & & 159.9 \\
\hline $6^{\prime}$ & & 116.2 \\
\hline $7^{\prime}$ & & 139.6 \\
\hline $8^{\prime}$ & $2.48 \mathrm{~s}$ & 20.0 \\
\hline $\mathrm{OCH}_{3}$ & $3.90 \mathrm{~s}$ & 56.6 \\
\hline $3^{\prime}-\mathrm{OH}$ & $11.30 \mathrm{~s}$ & \\
\hline
\end{tabular}

and all purified compounds were also isolated from the mycelium of $A$. ostoyae for the first time.

Extracts and the pure compounds 3 and 4 exhibited certain cytotoxic activity. In the extracts, cytotoxicity was time dependent and stronger after $24 \mathrm{~h}$ than after $1 \mathrm{~h}$. After $1 \mathrm{~h}$, the $\mathrm{IC}_{50}$ for cytotoxic activity was one order of magnitude higher than the $\mathrm{IC}_{50}$ of degranulation inhibition. The $\mathrm{IC}_{50}$ of degranulation inhibition, therefore, is not due to a cytotoxic effect. The enzyme $\beta$-hexosaminidase is a membrane-bound enzyme. If the membranal function is disturbed because of cell damage, the enzyme would no longer be placed in the membrane, but dissolved in the supernatant, resulting in a higher activity. This effect is used for standardisation of the test, as the $\beta$-hexosaminidase activity of the cell lysis is set to $100 \%$. The effect also is not caused by direct inhibition of the reporter $\beta$-hexosaminidase, as extracts and substances showed no significant inhibition of this enzyme (data not shown).

A. ostoyae is an edible mushroom, but should be cooked before consumption to avoid gastrointestinal problems. Honey mush- 
rooms are widely used as food and until now, no toxicological risks have been reported. Through the intake of $A$. ostoyae, no problematic health issues should emerge. Also, cytotoxicity has already been observed in this mushroom. In the future, $A$. ostoyae could play a supporting role in the therapy of allergies.

\section{Materials and Methods}

\section{Cell lines, chemicals, and biochemicals}

Adherent RBL-2H3 cells were obtained from DSMZ (Braunschweig, Germany). Cells were cultured in DMEM (Sigma; PAA) with $1 \%$ penicillin/streptomycine (Sigma) and $8 \%$ FCS (Sigma). Cells were incubated at $37^{\circ} \mathrm{C}$ in a humidified atmosphere with $95 \%$ air and $5 \% \mathrm{CO}_{2}$.

The composition of Tyrode's buffer was as follows [31]: $\mathrm{NaCl}$ $130 \mathrm{mM}, \mathrm{KCl} 5 \mathrm{mM}, \mathrm{CaCl}_{2} \times 2 \mathrm{H}_{2} \mathrm{O} 1.4 \mathrm{mM}, \mathrm{MgCl}_{2} \times 6 \mathrm{H}_{2} \mathrm{O} 1 \mathrm{mM}$, HEPES $10 \mathrm{mM}$, glucose $5.6 \mathrm{mM}$, BSA $0.1 \%$ or $0.1 \mathrm{~mL} / \mathrm{L}$ of a $7.5 \%$ BSA solution (Sigma). Anti-DNP IgE antibody was also obtained from Sigma (D8406).

\section{Fungal material and species determination}

Fresh fruiting bodies of $A$. ostoyae were collected in a forest near Greifswald, Germany (54 $4^{\circ} 31.51^{\prime \prime} \mathrm{N} ; 13^{\circ} 18^{\prime} 30.46^{\prime \prime} \mathrm{E}$ ), within an environment consisting mainly of coniferous trees. Fruiting bodies were cut in pieces, washed, frozen, and lyophilised. A voucher specimen is stored at the Institute of Pharmacy of the ErnstMoritz-Arndt University Greifswald (no. AoFrK_PMIO). Mycelium of $A$. ostoyae was available from the mushroom collection of the Institute of Pharmacy of the Ernst-Moritz-Arndt-University Greifswald (no. AoM_PMIO), Germany and cultivated for 3 weeks in Hagem medium pH5.4 (composition: ammonium succinate $0.5 \mathrm{~g}, \mathrm{KH}_{2} \mathrm{PO}_{4} 0.5 \mathrm{~g}, \mathrm{MgSO}_{4} \times 7 \mathrm{H}_{2} \mathrm{O} 0.5 \mathrm{~g}, 1 \% \mathrm{FeCl}_{3}$ solution $0.5 \mathrm{~mL}$, glucose $5 \mathrm{~g}$, malt extract $\mathrm{R} 25 \mathrm{~g}$, Aq. dest. $1 \mathrm{~L}$ ) at room temperature in a day-night rhythm, filtered from the culture broth, frozen, and freeze-dried. Before extraction, freeze-dried fruiting bodies and mycelium were ground to a powder. The extraction of fungal DNA, PCR of the fungal ITS rDNA, the official fungal barcode [32], and Sanger sequencing followed approved protocols [33]. DNA was extracted using a CTAB/chloroform/isoamylic alcohol/isopropanol protocol. After extraction and drying of DNA, amplification of the ITS region of the ribosomic DNA was done by PCR applying standard concentrations and conditions on

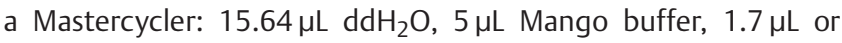
$50 \mathrm{mM} \mathrm{MgCl} 2$ solution, $0.5 \mu \mathrm{L} 10 \mathrm{mM}$ dNTP, $0.5 \mu \mathrm{L}$ of each primer (10 pM), $0.16 \mu \mathrm{L}$ Taq DNA polymerase $(5 \mathrm{U} / \mu \mathrm{L})$, and $1 \mu \mathrm{L}$ template DNA. Time program: $5 \mathrm{~min}$ at $94^{\circ} \mathrm{C}$, followed by 35 cycles $35 \mathrm{~s}$ at $94^{\circ} \mathrm{C}, 50 \mathrm{~s}$ at $52^{\circ} \mathrm{C}, 90 \mathrm{~s}$ at $72^{\circ} \mathrm{C}$, and 5 min at $72^{\circ} \mathrm{C}$ in the end. The PCR product was run on $0.8 \%$ agarose gel. Sequencing was done in the Botanical Institute of the Ernst-Moritz-Arndt University Greifswald, Germany.

Published sequences were exported from GenBank [34], aligned by MAFFT [35, 36], and converted with Mesquite [37] into a NEXUS-file for the calculation of a phylogeny in MrBayes and RAxML. Graphical illustration was done by SeaView [38], MEGA [39], or TreeViewX 0.5 [40]. Species determination was realised with field observations (e.g., densly growing basidiomata, pres- ence of rhizomorphs) and with macroscopic characteristics of fresh material (annulus, colorisation). ITS sequences were matched against published sequences. Similarity analysis with MrBayes (Bayesian inference approach) [41] and RaxML (Maximum likelihood approach) $[42,43]$ was used to confirm the secure placement of the own sequence within a clade of publicly available and published sequences of $A$. ostoyae (graphics can be found in Supporting Information).

\section{Extraction of biomass and isolation of compounds}

For preparation of the extracts for biological testing, biomass (fruiting bodies: ca. $25 \mathrm{~g}$, mycelium: ca. $15 \mathrm{~g}$ ) was extracted for $24 \mathrm{~h}$ with $500 \mathrm{~mL}$ solvent in a $250-\mathrm{mL}$ Soxhlet apparatus. Successive extraction was in the order dichloromethane, methanol, water. Extracts were filtered through filter paper, the volume decreased under reduced pressure. Drying was done by evaporation of dichloromethane and methanol, followed by lyophilisation when the extracts were not completely dry. Water extracts were dried by lyophilisation only.

Extraction with succeeding isolation of the compounds was done with $500 \mathrm{~mL}$ dichloromethane in $1 \mathrm{~L}$ glass flasks at room temperature for $3 \times 24 \mathrm{~h}$. The solvent volume was $500 \mathrm{~mL}$ for each step. Extracts were filtered through filter paper and the volume decreased under reduced pressure at a temperature of ca. $40^{\circ} \mathrm{C}$. Drying was done by evaporation of dichloromethane at room temperature.

Sesquiterpene aryl esters were isolated from the dichloromethane extract $(893 \mathrm{mg}$ ) prepared by the flask method. The biomass was extracted with $500 \mathrm{~mL}$ dichloromethane in a 1-L glass flask at room temperature for $3 \times 24 \mathrm{~h}$. Extracts were filtered through filter paper and the volume decreased under reduced pressure at a temperature of ca. $40^{\circ} \mathrm{C}$. Drying was done by evaporation of dichloromethane at room temperature. After that, a fractionation by column chromatography on silica gel 0.040 $0.063 \mathrm{~mm}$ (Merck; ca. $155 \mathrm{~g}$ stationary phase, column dimensions: diameter $3 \mathrm{~cm}$, height $41 \mathrm{~cm}$ ) with an $n$-hexane/ethanol/dichloromethane/methanol (elution steps: $n$-hexane; $n$-hexane/ ethanol 80:20; dichloromethane/methanol 90:10; methanol) gradient took place, yielding 5 fractions. Fractions 2, 3, and 4 (101 mg) were combined and subjected to another column chromatography on silica gel (ca. $50 \mathrm{~g}$ stationary phase, column dimensions: diameter $2 \mathrm{~cm}$, height $39 \mathrm{~cm}$ ) with a toluene/acetone gradient (toluoene/acetone 90:10, 75:25, 50:50, methanol), resulting in 11 fractions. Isolation of methyl linoleate from the dichloromethane extract $(749 \mathrm{mg})$ prepared at room temperature was done by C18E SPE ( $20 \mathrm{~g}$ cartridge; Phenomenex) with elution by an isopropanol/water gradient (elution steps: isopropanol $60 \%$; isopropanol $70 \%$; isopropanol $80 \%$; isopropanol). The $70 \%$ isopropanol fraction $(85 \mathrm{mg}$ ) was further purified by semipreparative HPLC, the last purification step for all substances. A Luna ${ }^{\circledR}$ C5 $250 \times 10 \mathrm{~mm}$ column, particle size $5 \mu \mathrm{m}, 100 \AA$ (Phenomenex) was used as the stationary phase. The mobile phase consisted of water as A and acetonitrile as B (VWR) in the gradient elution. In the later work, an addition of $0.1 \%$ formic acid to acetonitrile was used. The flow rate was $4 \mathrm{~mL} / \mathrm{min}$, and the detection channels were $190 \mathrm{~nm}$ and $272 \mathrm{~nm}$. The time program was as follows: \% B (time): 60 (0 min), 80 (23.5 min), 100 (24.5 min), 100 (29.5 min), 
60 (31.5 min), 60 (37 min). The gradient was modified or shortened when possible, whereas the gradient slope was the same in all runs. The time program was as follows: \% B (time) in isolation of methyl linoleate: 78 (0 min), 92 (23.5 min), 100 (24.5 min), 100 (29.5 min), 78 (31.5 min), 78 (37 min). After isolation, substances were tested for purity by HPLC with foregoing gradients.

\section{Characterisation of isolated compounds}

${ }^{1} \mathrm{H}$ NMR spectra were recorded at $400 \mathrm{MHz}$ and $27^{\circ} \mathrm{C}$; solvent deuterochloroform. 2D spectra were measured at $500 \mathrm{MHz}, 27^{\circ} \mathrm{C}$; solvent deuteromethanol or deuterochloroform. High-resolution mass spectra were obtained from a maXix 4G TOF-MS system (Bruker) by flow injection analysis of the compounds. The CD spectrum in the wavelength range of $200-400 \mathrm{~nm}$ of 13-hydroperoxyarmillarinin was measured with a JASCO T-810 system (JASCO) using isopropanol as the solvent. The IR spectrum of 13hydroperoxyarmillarinin was recorded on an Alpha FTIR spectrometer (Bruker). Spectral data of the known compounds can be found in the literature indicated.

Compound 1 from fraction 1 (1.4 mg): Resin. UV [ $\mathrm{L} \times \mathrm{mol}^{-1} \times$ $\left.\mathrm{cm}^{-1}\right]: \varepsilon_{219}=8272, \varepsilon_{238}=4440, \varepsilon_{271}=1678, \varepsilon_{283}=1206, \varepsilon_{326}=$ 617. $\mathrm{CD}\left[1 \times \mathrm{mol}^{-1} \times \mathrm{cm}^{-1}\right]: \Delta \varepsilon_{219}=0.29, \Delta \varepsilon_{238}=-0.91, \Delta \varepsilon_{271}=$ $0.023, \Delta \varepsilon_{283}=-0.044, \Delta \varepsilon_{326}=0.34$. Absolute configuration was as described by Kobori et al. [25]. IR $v\left[1 \times \mathrm{cm}^{-1}\right]: 1726 \mathrm{~s}$ (C=O st, Ester), $1666 \mathrm{~s}$ ( $\mathrm{C}=\mathrm{O}$ st, aldehyde), $2926 \mathrm{~m}$ (=CH st), $2854 \mathrm{~m}$ (-CH st), 3353 b (O-H st, coordinated). Monoisotopic mass 480.1551. $(+)$-HRESIMS $503.1443\left[\mathrm{M}+\mathrm{Na}^{+}\right](\delta=-0.040 \mathrm{ppm})$. Molecular formula $\mathrm{C}_{24} \mathrm{H}_{29} \mathrm{ClO}_{8}$.

Compound 2 from fraction 7 (3.6 mg) [10]: Monoisotopic mass 446.1941. Resin. (-)-HRESIMS 445.1864 $\left[\mathrm{M}-\mathrm{H}^{+}\right]^{+}(\delta=$ - 0.880 ppm). Molecular formula $\mathrm{C}_{24} \mathrm{H}_{30} \mathrm{O}_{8}$.

Compound 3 from fraction 4 (11.9 mg) [11]: Monoisotopic mass 430.1992. Resin. (+)-HRESIMS 453.1881 [M + $\left.\mathrm{Na}^{+}\right]^{+}(\delta=$ - 0.619 ppm). Molecular formula $\mathrm{C}_{24} \mathrm{H}_{30} \mathrm{O}_{7}$.

Compound 4 from fraction 4 (13.7 mg) [25]: Monoisotopic mass 464.1602. Resin. (+)-HRESIMS 487.1494 $\left[\mathrm{M}+\mathrm{Na}^{+}\right](\delta=$ - 1.133 ppm). Molecular formula $\mathrm{C}_{24} \mathrm{H}_{29} \mathrm{ClO}_{7}$.

Compound 5 from fraction 6 (3.3 mg) [12]: Monoisotopic mass 480.1551. Resin. (-)-HRESIMS 479.1478 [M $\left.-\mathrm{H}^{+}\right]^{+} \quad(\delta=$ - 0.116 ppm). Molecular formula $\mathrm{C}_{24} \mathrm{H}_{29} \mathrm{ClO}_{8}$.

Compound 6 from fraction 7 (2.9 mg) [15]: Monoisotopic mass 416.1835. Resin. (-)-HRESIMS 415.1755 [M $\left.-\mathrm{H}^{+}\right]^{+} \quad(\delta=$ - 1.734 ppm). Molecular formula $\mathrm{C}_{23} \mathrm{H}_{28} \mathrm{O}_{7}$.

Compound 7 from fraction 4 (2.4 mg) [22]: Resin. Monoisotopic mass 414.2042. (+)-HRESIMS 437.1935 $\left[\mathrm{M}+\mathrm{Na}^{+}\right]^{+}(\delta=$ $0.093 \mathrm{ppm})$. Molecular formula $\mathrm{C}_{24} \mathrm{H}_{30} \mathrm{O}_{6}$.

Compound 8 from fraction 4 (3.9 mg) [25]: Resin. Monoisotopic mass 448.1653. (+)-HRESIMS 471.1548 $\left[\mathrm{M}+\mathrm{Na}^{+}\right]^{+}(\delta=$ 0.693 ppm). Molecular formula $\mathrm{C}_{24} \mathrm{H}_{29} \mathrm{ClO}_{6}$.

Compound 9 was isolated by C18 SPE followed directly by semipreparative HPLC (3.6 mg): Oil. Molecular formula $\mathrm{C}_{19} \mathrm{H}_{34} \mathrm{O}_{2}$.

\section{Degranulation assay}

After trypsinisation, the cell concentration was adjusted to $5 \times 10^{5}$ cells/mL with DMEM. Four hundred $\mu \mathrm{L}$ of this suspension were given into a well of a 24 -well plate (i.e., $2 \times 10^{5}$ cells/well). Subsequently, $100 \mu \mathrm{L}$ of a $495 \mathrm{ng} / \mathrm{mL}$ solution of $\mathrm{lgE}$ in PBS (phosphate buffered saline) (without $\mathrm{Ca}$ and $\mathrm{Mg}$, PAA) were added into the wells for the determination of the positive control and test samples, and $100 \mu \mathrm{L}$ PBS (without $\mathrm{Ca}$ and $\mathrm{Mg}$ ) were added into the wells for determination of spontaneous degranulation and cell lysis. Cells were incubated overnight at $37^{\circ} \mathrm{C}$ in a humidified atmosphere with $95 \%$ air and $5 \% \mathrm{CO}_{2}$.

The supernatant was removed and the cells were washed with $500 \mu \mathrm{L}$ of Tyrode's buffer. Then, $497 \mu \mathrm{L}$ (for testing of raw extracts) or $498 \mu \mathrm{L}$ (fractions and purified compounds) were added to the wells for tests samples, $500 \mu \mathrm{L}$ for the positive control ("pos"), and $510 \mu \mathrm{L}$ for the determination of spontaneous degranulation ("neg"). In the wells for cell lysis, $510 \mu \mathrm{L}$ of a $0.1 \%$ solution of Triton X-100 in Tyrode's buffer was pipetted. Cells were incubated for $10 \mathrm{~min}$. Then, $3 \mu \mathrm{L}$ (raw extracts) or $2 \mu \mathrm{L}$ (fractions, purified compounds) of test samples were added into corresponding wells followed by incubation for $10 \mathrm{~min}$. Cell stimulation was done by $10 \mu \mathrm{L}$ of a $50 \mu \mathrm{g} / \mathrm{mL}$ solution of DNP-HSA (Sigma) in PBS for all cells except those for spontaneous degranulation and cell lysis. A blank was measured with $510 \mu \mathrm{L}$ Tyrode's buffer without cells.

For the $\beta$-hexosaminidase assay, $50 \mu \mathrm{L}$ of the supernatant of each well were transferred to a 96 -well plate and $50 \mu \mathrm{L}$ of the $\beta$ hexosaminidase substrate $\mathrm{p}-\mathrm{NAG}, 1.2 \mathrm{mM}$ in $0.1 \mathrm{M}$ sodium acetate buffer ( $\mathrm{pH} 4.5$ ), were added followed by incubation for $2 \mathrm{~h}$. The reaction was stopped with $150 \mu \mathrm{L}$ of $0.4 \mathrm{M}$ glycine buffer $\mathrm{pH} 10.7$ (glycine was from Merck). Absorption was measured in a microtitre plate reader (BMG Labtech) at $405 \mathrm{~nm}$. From all values, the blank was subtracted. An IC $\mathrm{C}_{50}$ value was determined for the reference substance quercetin (purity $\geq 95 \%$; Sigma).

For determination of the direct inhibition of $\beta$-hexosaminidase, after seeding of the cells, $100 \mu \mathrm{L}$ PBS (without Ca and Mg, PAA) were added to each well. After incubation overnight, cells were washed with $500 \mu \mathrm{L}$ of Tyrode's buffer and $0.1 \%$ Triton X-100 (Sigma) solution in Tyrode's buffer and added as follows: $510 \mu \mathrm{L}$ for cell lysis and blank, $508 \mu \mathrm{L}$ to the wells destined for test samples. After incubation for $10 \mathrm{~min}, 2 \mu \mathrm{L}$ of test samples were added, followed by incubation for $10+30$ min (time period necessary for the degranulation assay). Fifty $\mu \mathrm{L}$ of the supernatant were transferred to a 96-well plate for determination of $\beta$-hexosaminidase activity as described above.

\section{Neutral red uptake assay}

The assay was conducted in a 96-well plate. In brief, 15000 cells suspended in $100 \mu \mathrm{L}$ medium were sown into each well. Wells on the periphery of the plate were filled with medium only, followed by incubation overnight. On the next day, the medium was removed from all wells and in all columns, except for columns 3 and $11,150 \mu \mathrm{L}$ of medium were added. Columns 3 and 11 were filled with $100 \mu \mathrm{L}$ of medium. Into column $4,150 \mu \mathrm{L}$ of test sample were given and mixed thoroughly. Then, $150 \mu \mathrm{L}$ of the mixture were transferred from column 4 to column 5 , mixed thoroughly and $150 \mu \mathrm{L}$ was transferred to column 6 , etc. From the last column, $150 \mu \mathrm{L}$ were removed and discarded. Into column 3, $50 \mu \mathrm{L}$ of the positive control (etoposid in medium) were pipetted, and into column $11,50 \mu \mathrm{L}$ of the solvent in the concentration used in column 3 were pipetted. Cells were incubated for $24 \mathrm{~h}$. Subsequently, the medium was removed and cells were washed with 
$200 \mu \mathrm{L}$ of HBSS (Sigma). Into all wells, $100 \mu \mathrm{L}$ of a solution of neutral red in medium were added and cells were incubated for $3 \mathrm{~h}$. Neutral red can be accumulated by living cells only. After the incubation period, the neutral red solution was aspirated and cells were washed two times with $100 \mu \mathrm{L}$ HBSS each. Next, $100 \mu \mathrm{L}$ ethanol/glacial acetic acid solution were added to each well for cell lysis and dissolution of the dye. Microwell plates were shaken for $45 \mathrm{~min}$, followed by absorption measurement at $540 \mathrm{~nm}$ in a microtitre plate reader (BMG Labtech). An IC 50 value of cytotoxicity was reported for the reference substance etoposid (purity $\geq 98 \%$; Sigma).

For testing of an effect of substances, extracts, or fractions after $1 \mathrm{~h}$, cells were incubated for $48 \mathrm{~h}$ after seeding. Then the test was conducted as described above.

\section{Statistical analysis}

Determination of $\mathrm{IC}_{50}$ values was done with the software GraphPad Prism ${ }^{\circledR}$ version 6 using nonlinear regression with four parameters and a variable slope option. Significance was tested by unpaired Welch's t-test.

\section{Supporting information}

Graphics from RAxML and MrBayes for species determination of the mycelium of $A$. ostoyae (Fig. S1-S2), CD, ATIR, and UV spectra and ${ }^{1} \mathrm{H}$ - as well as ${ }^{1} \mathrm{H},{ }^{1} \mathrm{H}$-COSY NMR spectra of 1 (Fig. S3-S8), and LC chromatograms of crude extracts and active fractions (Fig. S9S11) are available as Supporting Information.

\section{Acknowledgements}

We thank Michael Eccius (EMAU Greifswald) for measurement of the IR spectrum of 13-hydroperoxyarmillarinin and Jonathan Dickerhoff (EMAU Greifswald) for support in the recording of the CD spectra. Likewise, we thank Mrs. Monika Matthias (EMAU Greifswald) for excellent technical support, especially in the cultivation of the mycelium of $A$. ostoyae.

\section{Conflict of Interest}

The authors declare no conflict of interest.

\section{References}

[1] Romagnesi H. Observations on Armillaria. Bull Trimest Soc Mycol Fr 1970; 86: 257-265

[2] Dobbertin M, Baltensweiler A, Rigling D. Tree mortality in an unmanaged mountain pine (Pinus mugo var. uncinata) stand in the Swiss National Park impacted by root rot fungi. For Ecol Manage 2001; 145 : 79-89

[3] Cleary MR, van der Kamp B], Morrison DJ. Effects of wounding and fungal infection with Armillaria ostoyae in three conifer species. II. Host response to the pathogen. Forest Pathol 2011; 42: 109-123

[4] Cleary MR, van der Kamp B], Morrison DJ. Effects of wounding and fungal infection with Armillaria ostoyae in three conifer species. I. Host response to abiotic wounding in non-infected roots. Forest Pathol 2012; 42: 100108
[5] Cruickshank M, Morrison D], Lalumière A. The interaction between competition in interior Douglas-fir plantations and disease caused by Armillaria ostoyae in British Columbia. For Ecol Manage 2009; 257: 443-452

[6] Entry JA, Cromack jr. K, Hansen E, Waring R. Response of western coniferous seedlings to infection by Armillaria ostoyae under limited light and nitrogen. Phytophathology 1991; 81: 89-94

[7] Pearce RB. Tansley Review No. 87. Antimicrobial defences in the wood of living trees. New Phytol 1996; 132: 203-233

[8] Schmitt CL, Tatum ML. The Malheur national forest: Location of the world's largest living organism [The humongous fungus]. Portland, Oregon: United States Department of Agriculture (USDA), Forest Service, Pacific Northwest Region; 2008

[9] Mihail JD. Bioluminescence patterns among North American Armillaria species. Fungal Biol 2015; 119: 528-537

[10] Arnone A, Cardillo R, Nasini G. Structures of melleolides B-D, three antibacterial sesquiterpenoids from Armillaria mellea. Phytochemistry 1986; 25: $471-474$

[11] Arnone A, Cardillo R, Di Modugno V, Nasini G. Secondary mold metabolites. XXII. Isolation and structure elucidation of melledonals D and $E$ and melleolides $\mathrm{E}-\mathrm{H}$, novel sesquiterpenoid aryl esters from Clitocybe elegans and Armillaria mellea. Gazz Chim Ital 1988; 118: 517-521

[12] Arnone A, Cardillo R, Nasini G. Secondary mould metabolites. Part 19. Structure elucidation and absolute configuration of melledonals $B$ and C, novel antibacterial sesquiterpenoids from Armillaria mellea. X-ray molecular structure of melledonal C. J Chem Soc Perkin Trans I 1988; 503510

[13] Chen CC, Kuo YH, Cheng JJ, Sung PJ, Ni CL, Chen CC, Shen CC. Three new sesquiterpene aryl esters from the mycelium of Armillaria mellea. Molecules 2015; 20: 9994-10003

[14] Donnelly DMX, Sanada S, O’Reilly J, Polonsky J, Prangé T, Pascard C. Isolation and structure (X-ray analysis) of the orsellinate of armillol, a new antibacterial metabolite from Armillaria mellea. J Chem Soc Chem Commun 1982; 135-137

[15] Donnelly DMX, Hutchinson RM, Coveney D, Yonemitsu M. Sesquiterpene aryl esters from Armillaria mellea. Phytochemistry 1990; 29: 2569-2572

[16] Donnelly DMX, Abe F, Coveney D, Fukuda N, O'Reilly J. Antibacterial sesquiterpene aryl esters from Armillaria mellea. J Nat Prod 1985; 48: $10-16$

[17] Liu TP, Chen CC, Shiao PY, Shieh HR, Chen YY, Chen Y]. Armillaridin, a honey medicinal mushroom, Armillaria mellea (higher basidiomycetes) component, inhibits differentiation and activation of human macrophages. Int J Med Mushrooms 2015; 17: 161-168

[18] Midland SL, Izac RR, Wing RM, Zaki A, Munnecke D, Sims JJ. Melleolide, a new antibiotic from Armillaria mellea. Tetrahedron Lett 1982; 23: 25152518

[19] Momose I, Sekizawa R, Hosokawa N, linuma H, Matsui S, Nakamura H, Naganawa H, Hamada M, Takeuchi T. Melleolides K, L and M, new melleolides from Armillaria mellea. J Antibiot 2000; 53: 137-143

[20] Yang JS, Su YL, Wang YL, Feng XZ, Yu DQ, Liang XT. Two novel protoilludane norsesquiterpenoid esters, armillasin and armillatin, from Armillaria mellea. Planta Med 1991; 57: 478-480

[21] Arnone A, Cardillo R, Nasini G. Secondary mould metabolites. XXIII. Isolation and structure elucidation of melleolides I and J and armellides $A$ and $\mathrm{B}$, novel sesquiterpenoid aryl esters from Armillaria novae-zelandiae. Gazz Chim Ital 1988; 118: 523-527

[22] Donnelly DMX, Konishi T, Dunne O, Cremin P. Sesquiterpene aryl esters from Armillaria tabescens. Phytochemistry 1997; 44: 1473-1478

[23] Cell Degranulation - MeSH - NCBI. Available at https://www.ncbi.nlm. nih.gov/mesh/?term=cell+degranulation. Accessed October 5, 2016

[24] Mastuda H, Morikawa T, Ueda K, Yoshikawa M. Structural requirements of flavonoids for inhibition of antigen-induced degranulation, TNF- $\alpha$ and 
IL-4 production from RBL-2H3 cells. Bioorg Med Chem 2002; 10: 3123 3128

[25] Kobori H, Sekiya A, Suzuki T, Choi JH, Hirai H, Kawagishi H. Bioactive sesquiterpene aryl esters from the culture broth of Armillaria sp. J Nat Prod 2015; 78: 163-167

[26] Appendino G, Gariboldi P, Menichini F. Oxygenated nerolidol derivatives from Artemisia alba. Phytochemistry 1985; 24: 1729-1733

[27] Yang JS, Su YL, Wang YL, Feng XZ, Yu DQ, Liang XT. Chemical constituents of Armillaria mellea mycelium. V. Isolation and characterization of armillarilin and armillarinin. Yao Xue Xue Bao 1990; 25: 24-28

[28] Bohnert M, Nützmann HW, Schroeckh V, Horn F, Dahse HM, Brakhage AA, Hoffmeister D. Cytotoxic and antifungal activities of melleolide antibiotics follow dissimilar structure - activity relationships. Phytochemistry 2014; 105: 101-108

[29] Bohnert M, Miethbauer S, Dahse HM, Ziemen J, Nett M, Hoffmeister D. In vitro cytotoxicity of melleolide antibiotics: structural and mechanistic aspects. Bioorg Med Chem Lett 2011; 21: 2003-2006

[30] Misiek M, Williams ], Schmich K, Hüttel W, Merfort I, Salomon CE, Aldrich CC, Hoffmeister D. Structure and cytotoxicity of arnamial and related fungal sesquiterpene aryl esters. J Nat Prod 2009; 72: 1888-1891

[31] Abramson ], Pecht I. Clustering the mast cell function-associated antigen (MAFA) leads to tyrosine phosphorylation of p62Dok and SHIP and affects RBL-2H3 cell cycle. Immunol Lett 2002; 82: 23-28

[32] Schoch CL, Seifert KA, Huhndorf S, Robert V, Spouge JL, Levesque CA, Chen W. Nuclear ribosomal internal transcribed spacer (ITS) region as a universal DNA barcode marker for fungi. Proc Natl Acad Sci U S A 2012; 109: 6241-6246

[33] Solis MJL, Yurkov A, dela Cruz TE, Unterseher M. Leaf-inhabiting endophytic yeasts are abundant but unevenly distributed in three Ficus spe- cies from botanical garden greenhouses in Germany. Mycol Prog 2015; 14: 1019

[34] Benson DA, Cavanaugh M, Clark K, Karsch-Mizrachi I, Lipman D], Ostell ], Sayers EW. GenBank. Nucleic Acids Res 2012; 41: D36-D42

[35] Katoh K, Misawa K, Kuma K, Miyata T. MAFFT: a novel method for rapid mulitple sequence alignment based on fast Fourier transform. Nucleic Acids Res 2002; 30: 3059-3066

[36] Katoh K, Standley DM. MAFFT multiple sequence alignment software version 7: improvements in performance and usability. Mol Biol Evol 2013; 30: 772-780

[37] Maddison WP, Madisson DR. Mesquite: a modular system for evolutionary analysis, Version 2.75. Available at http://mesquiteproject.org

[38] Gouy M, Guindon S, Gascuel O. SeaView version 4: A multiplatform graphical user interface for sequence alignment and phylogenetic tree building. Mol Biol Evol 2010; 27: 221-224

[39] Tamura K, Stecher G, Peterson D, Filipski A, Kumar S. MEGA6: Molecular evolutionary genetics analysis version 6.0. Mol Biol Evol 2013; 30: 27252729

[40] Page RD. TreeView: an application to display phylogenetic trees on personal computers. Comput Appl Biosci 1996; 12: 357-358

[41] Huelsenbeck JP, Ronquist F. MRBAYES: Bayesian inference of phylogenetic trees. Bioinformatics 2001; 17: 754-755

[42] Stamatakis A. RAxML version 8: a tool for phylogenetic analysis and postanalysis of large phylogenies. Bioinformatics 2014; 30: 1312-1313

[43] Silvestro D, Michalak I. raxmlGUI: a graphical front-end for RAxML. Org Divers Evol 2012; 12: 335-337 